\title{
Sonhos sem alicerces, radiantes prélios
}

\author{
Marcelo Calderari Miguel ${ }^{1}$
}

Sina longa, correspondência breve... Muita tecnologia marca a vida.

Queria inovação e grandeza, almejava-a menos desunida.

Pouco a pouco finda a fantasia, emblemática arte proibida.

Pela tangente apatia desmedida, deflagrada uma blindagem corrompida.

Breve, semibreve, muito breve é a alegria.

Às vezes é um concerto de euforia, mister lógica e utopia.

Outras vezes é um descompasso de harmonia, enigma e nostalgia.

Algum momento e não muito raro, transparece uma alucinação coletiva.

Insana e prática existência, fomenta um sugado coração.

Pura subversão, pusilanimidade edificada, pavor que se altera em hesitação.

Pouco viver desvenda contradição, avança a sutil alma uma certeira desilusão.

Essência moribunda, corta impérios, engana a esperança do mundo.

Reflete infecunda experiência, espúria vingança, um desmoronar profundo.

Se a paixão é alcatraz ferrugenta, o amar - muda tudo - é primado certo e transfundo.

1 Especialista em Educação Científica pela Universidade Federal de Minas Gerais (UFMG); Bacharel em Administração e Bibliotecomia pela Universidade Federal do Espírito Santo (UFES). Pesquisador no Núcleo de Pesquisa 'Tabularium' Políticas de Arquivos: Observatório no Estado do Espírito Santo | ORCID 0000-0002-7876-9392. E-mail: marcelocalderari@yahoo.com.br 